\title{
The onus on us? Stage one in developing an i-Trust model for our users.
}

\author{
Alison Jane Pickard, Pat Gannon-Leary, Lynne Coventry
}

\begin{abstract}
This article describes a Joint Information Systems Committee (JISC)-funded project, conducted by a cross-disciplinary team, examining trust in information resources in the web environment employing a literature review and online Delphi study with follow-up community consultation. The project aimed to try to explain how users assess or assert trust in their use of resources in the web environment; to examine how perceptions of trust influence the behavior of information users; and to consider whether ways of asserting trust in information resources could assist the development of information literacy. A trust model was developed from the analysis of the literature and discussed in the consultation. Elements comprising the i-Trust model include external factors, internal factors and user's cognitive state. This article gives a brief overview of the JISC funded project which has now produced the i-Trust model (Pickard et. al., 2010) and focuses on issues of particular relevance for information providers and practitioners.
\end{abstract}

\section{Introduction}

Recently the gauntlet has been thrown down to information providers. Firstly, we were challenged by the CIBER project's message about young users of library services:

We know that younger scholars especially have only a very limited knowledge of the many library-sponsored services that are on offer to them. The problem is one of both raising awareness of this expensive and valuable content and making the interfaces much more standards and easier to use. The cognitive load on any

\section{Authors}

Alison Jane Pickard is Head of Information and Communication Management and Director of Quality and Student Experience for the School of Computing, Engineering and Information Sciences, Northumbria University.

Email: alison.pickard@ @orthumbria.ac.uk

Pat Gannon-Leary has worked in HEIs for many years and has 12 years experience as a researcher.

Lynne Coventry is Co-Director of the Psychology and Communications Technology Lab where she runs projects in relation to usability, trust and privacy perceptions. 
library user (or librarian) in trying to work through such complexity is at present immense. Librarians are guilty of complacency here.

(University College London, 2008, 30).

Another challenge came from Anderson's (2010) contention that:

"Librarians response to the Google Book Search (GBS) juggernaut has, generally been that of an ostrich that pauses, as it whistles past the graveyard, only long enough to stick its head in the sand..."

(Anderson, 2010, 38)

These charges of being complacent or ostrich-like may seem unfair but information providers are certainly facing new challenges in the $21^{\text {st }}$ Century. Whilst the availability of previously inaccessible information may have increased the onus on the end user to locate and evaluate information resources, it has also increased the onus on us as information providers to demonstrate our own credibility and value outside of bounded systems such as 'trusted library gateways'.

Engendering trust in Web resources which operate outside of conventional 'gateway' services has become increasingly more important given that, as the CIBER project reports, end users don't necessarily use digital media "in the ways that librarians assume. Any barrier to access, be that additional log-ins, payment or hard copy, is too high for most consumers and information behind those barriers will increasingly be ignored" (University College London, 2008, 30)

If end users are not using trusted gateways then how do we certify the authenticity and provenance of digital information resources and, indeed, is this certification necessary? This is one of the questions raised by a recent Joint Information Systems Committee (JISC) funded project on i-Trust, aims of which included the provision of an overview of how trust is assessed/asserted in relation to the use/provision of digital resources; assessment of whether establishing ways to assert trust in those resources could assist the development of information literacy (IL); and increase in understanding of how perceptions of trust influence the behaviour of end users.

\section{Methodology}

The first phase of the project methodology comprised desk-based reviews of relevant literature that analysed and synthesised the outcomes of existing research and studies on how users place their trust in digital information resources in the web environment and means by which digital information providers currently engender trust in their resources. In doing this, a systematic literature review was undertaken, modified in respect of scope and depth which was very focused due to the short project timescale ( 4 months). The rationale for this approach was that it would ensure the selection of relevant, quality work from what was available using an efficient technique that minimised bias. The ultimate selection of references to include in the study was made on the basis of their appropriateness to the aims of the project and to a model of i-trust which was concurrently being developed by the team. 
The second phase of the project methodology involved community consultation (Lappin and McLeod, 2010) of the findings from phase 1 with users and providers, using an on-line modified Delphi study and a round table (Pickard, 2007). This was to validate and extend the findings from the literature review; to establish users' and providers' perceptions of the desirability and feasibility of certifying authenticity and provenance and, in addition, to explore the potential for developing a framework of trust that could help develop information literacy. The Delphi study method was chosen because it is fast and relatively inexpensive, given the short project timescale. The on-line modified Delphi study used a brief questionnaire to establish the baseline. By canvassing individual written comments on particular questions the team hoped to be able to combine these to form consensus.

The team initially sent out an email about the project to users (students, academic tutors and researchers) and providers (commercial service providers and HE information service providers) from the North East of England (in the case of the HEIs, the two contacts were Northumbria and Newcastle, representing new and old institutions). The initial email explained that there was to be a round table event, to which they were invited, and that this was preceded by a brief email questionnaire. Only those who responded positively to this initial email were sent a follow-up email with the questionnaire attached. Respondents had no overt contact with each other during this process - thus avoiding pressure to conform or dominance by individuals that are inherent weaknesses of methods such as focus groups - and were unaware who else had received the questionnaire and been invited to the round table event.

The team analysed the responses to the questionnaire prior to the round table event, comparing instances from the questionnaire data to identify tentative categories and their properties and trying to aggregate the responses into a preliminary consensus. It was anticipated that emergent elements from analysis of individual responses would be modified and developed by comparison with instances from the subsequent round table phase and that further categories and properties might emerge. A synthesis of the original questionnaire responses was returned to all round table participants prior to the face to face consultation. A putative trust model had been developed on the basis of the phase 1 literature review and, after analysis by the team, the responses were mapped on to this as a preliminary exercise.

The purpose of the round table was to provide a review function, to assist in the confirmation of trends established from the literature about users, and to identify which of those trends are likely to be worthy of further investigation, including the desirability and feasibility of certifying the authenticity and provenance of digital information resources. The round table was in essence a semi-structured face-to-face meeting of the individual questionnaire respondents who, having recorded their initial individual ideas, had the opportunity to share and discuss these - facilitated by the research team - and then engage in ranking procedures to assist in the determination of priorities. The event consisted of four activities based around consultation and negation. Applying the 'World Cafe' approach, participants were divided between four tables, each table being 
engineered to accommodate a pre-defined combination of users. (Pickard, et al., 2010)

\section{Findings}

From a review of the literature, three factors affecting trust/credibility of online information were identified: external factors, internal factors and user's cognitive state. It would appear that these cues influence a user's decision as to whether or not to conduct any further assessment of information as illustrated in the i-Trust model.

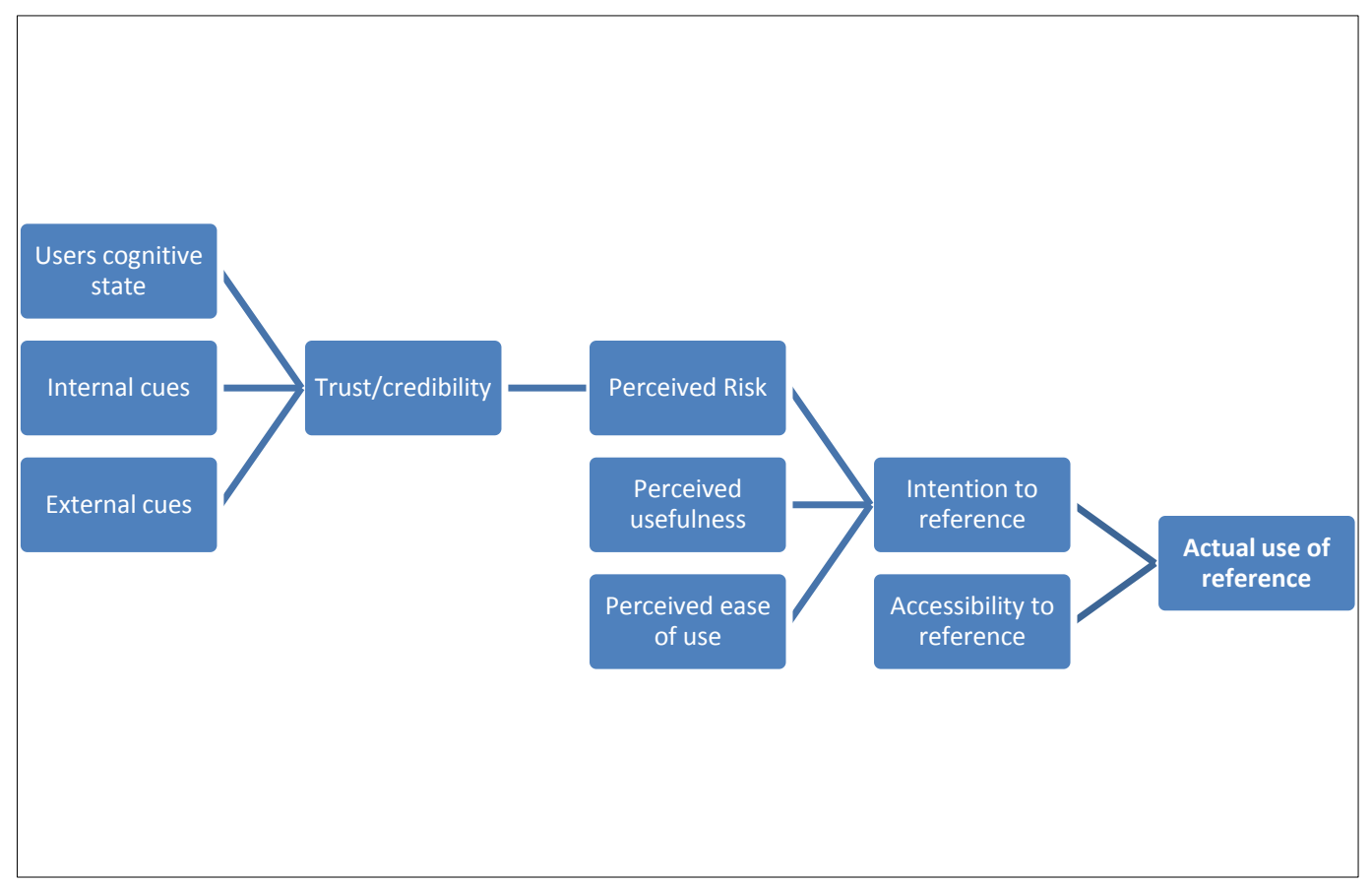

Figure 1: i-Trust Model: User trust in information resources in the web environment.

\subsection{External cues}

External factors impact on user beliefs about the usefulness and ease of use of information, giving external cues of trustworthiness. These include factors such as whether or not the information is free or paid for since student users are unlikely to use paid-for information (OCLC 2002; Weiler 2005). External cues include seals of approval such as those employed by Truste and the HON code of conduct, more commonly employed in the fields of e-health and e-commerce (Walsh 2007). Another cue, common in e-health and e-commerce, is the use of credibility rating systems, e.g. RATEWeb (Malik and Bouquettaya, 2009) that make use of authority, currency and objectivity of sites to rate them. Libraries could do something similar as an extension of their collection development function. Currently libraries do make use of pre-approved databases such as JSTOR or ERIC or their own local variant and these represent another external factor (Brophy and Bawden, 2005). If online resources were to specify the provenance (i.e. the original/context/history) of digital information that they supply - the way another external cue, digital signatures ensure the authenticity of author and 
information (Bradley, 2005) - would they be more likely to be trusted? Generally, in respect of evidence of provenance of online information, this is achieved by identification by a trusted third party such as a library or certified digital repository. Recommendations from other users, peer reviews, colleagues, lecturers or fellow students are becoming increasingly more familiar to end users. (Hertzum et. al., 2002). Most people have experience of using rating sites such as TripAdvisor or restaurant reviews and are aware that dissatisfied users are more likely to make postings than are satisfied customers and that consequently customers can rate web services incorrectly/unfairly, related to service behaviour (Letia and Pop, 2008). Could external cues such as these be employed in peer rating/peer review of scholarly information? Lynch (2001) discusses metadata and the suggestion that users would be willing to trust metadata created by information professionals such as librarians or archivists or such metadata certified or rated by information professionals. He goes on to say that such a system would require the existence of an organization that would license such professionals and, additionally, maintain a 'blacklist' of those found guilty of creating deceptive metadata. One would imagine that membership of a professional association such as CILIP should be a form of certification of the information professional and the degree of their trustworthiness to create or accredit such metadata.

What are users' opinions of the desirability of some form of certification? Calvert (2001) is one of the few researchers who have asked users about the desirability of controlling information quality on the Web by using some form of certification. Participants in his focus groups felt that this was neither possible nor fully desirable. Reasons for this included firstly the sheer size of the Web and the volume of information added that would make it impossible to keep up to date. Secondly there was concern that certification could lead to censorship. Those members of Calvert's (2001) focus groups who were more positive about certification felt that the certification by an impartial body of scholarly publications could improve the quality of information on the Web but generally there was feeling that the existing gate keeping procedures (i.e. peer review) of ejournals rendered further certification redundant.

\subsection{Internal cues}

Internal cues are concerned with information's trustworthiness including accuracy, authoritativeness, objectivity, currency, coverage, presentation and format, affiliations of source/site, citations and source motivation (i.e. why are they publishing this information? In studies of users' perceptions, authority features prominently in terms of both the organization (Liu, 2004) and the individual (Hung 2004; McKnight and Kacmar, 2006). The assumptions held by users that information is trustworthy or good because it comes from a certain organization lend presumed credibility (Liu 2004). Several authors have also stressed the need to cross check and verify that the same information is retrievable from several sources and to feel that all eventualities and arguments have been explored prior to taking the decision to cite a source. (Wachbroit, 2000; Burbules, 2001). The members of the i-Trust community consultation referred to examining the credibility of organizations, e.g. by checking out domain names; going beyond 
the company or individual name to explore the 'About us' part of websites. They mentioned taking decision about how 'academic' information is and highlighted the need to cross check and verify that the same information could be found in several sources and to feel that all eventualities and arguments have been explored prior to taking the decision to cite a source. (Burbules, 2001). Affiliation of an individual is another internal cue (Burbules, 2001; Liu and Huang, 2005; Swanson, 2007), in terms of which Liu (2004) found that affiliation with a prestigious institution was a more positive indicator of credibility than authorship by a famous 'expert'.

Coverage and currency also provides an internal cue (Metzger et al., 2003; Hung, 2004; Weiler, 2005), the i-Trust community consultation members commented on how time and cognitive stage determined the depth of coverage they required rather than the information per se. If they had limited time or there was likely to be one factual answer to their query, they needed less depth of coverage and therefore this would affect their choice of source. They were aware that the fact a web page had been updated did not mean that all the information contained had been similarly updated.

In terms of presentation, sites using graphics and multimedia are evaluated more highly by the 'Google generation' (Agosto, 2002). Hung (2004) found that, upon entering websites students made judgements based on surface characteristics, e.g. 'it looks scholarly', and peripheral cues Kulthau (1991; 1993a; 1993b) describes this as the affective side of information seeking as opposed to the cognitive/behavioural aspect of information seeking but, as Amichai-Hamburger et al. (2007) have identified that the need for cognition can influence user susceptibility to internal cues such as presentation of the site. The development of trust is through bonding using the influence of aesthetics and evoking an emotional response is something on which e-commerce organizations capitalize (Hertzum, 2002).

The type of object also influences trust, e.g. a journal, a blog (Princeton, 2005).was also a subject of discussion during the i-Trust community consultation. Blogs were mentioned as being trustworthy if the author of the blog was known to have posted in peer review journals, i.e. their reputation was established elsewhere but there was awareness that, more generally, blogs could be a source of bias.

\subsection{User's cognitive state}

In addition to external and internal cues, the user's cognitive state impacts on their beliefs about trustworthiness of online information sources. McKnight and Kacmar's (2006) study provides evidence that initial information credibility is built through three general dispositions: the disposition to trust; trust in technology; and risk propensity. Factors linked with cognitive state include need for closure and need for cognition (Amichai-Hamburger et al., 2007; Kaynar and Amichai-Hamburger, 2008) and a willingness to explore information (McKnight and Kacmar, 2006). In addition, there are factors related to prior knowledge (Rieh, 2002; Taraborelli, 2008), ability (Rowlands, 2008; Usher, 2009); past experience with authors and with web sources (Lim, 2009). The search purpose and time available (Metzer et al., 2003) are influential as are faith in, or suspicion of, humanity (McKnight and Kacmar, 2006). 
'Internet anxiety' (Tsai, 2001; McKnight and Kacmar, 2006) would appear not to be an issue for students (although it may be with mature students or with international students from less developed countries) but who are members of the 'Google generation' of students familiar with, and trusting of, Google and similar search engines. Students arrive in HE with an aptitude for using information communication and technology (ICT), an ability to multitask with diverse media and interactive work styles (Breeding 2006). However, most research studies indicate that students overrate their Internet skills/experience (Burhanna et al., 2009). Manual (2002) believes this may be attributable to perception of Internet as a 'cool' medium about which they are expected to know. To compound this, they tend to work independently with internet resources which is likely to impair their critical/evaluative abilities leading to misplaced confidence and trust in the web environment. For example, with respect to web search engines, Colaric's (2003) study found that students' existing knowledge of Web search engines and how they worked was, in the main, around 33-40\% incorrect. In terms of websites with advertising, students in the OCLC (2002) study perceived these as having equally reliable information to advertisement-free websites, with only $20 \%$ of the students believing that advertisement-free sites might have more reliable information. Students rate their abilities favourably, claiming they are successful finding information they need and know how to discriminate and choose the best information (OCLC, 2002; Buschman and Warner, 2005) Buschman and Warner's (2005) study corroborates findings of Grimes and Boening (2001) on student misplaced confidence in their Internet searching abilities as opposed to their actual research skills/performance. Hembroff (2006) discovered that threequarters of students used the Internet as their primary source for researching health information, despite the fact nearly a quarter (23\%) of their respondents had doubts about the Internet as a credible source of information.

Time available is another factor related to user's cognitive state (Metzger, 2007). In the case of student users this may be related to the amount of time they are willing to wait for information/help and their early experiences with ICT may have led them to expect information quickly from multiple sources in real-time for immediate processing and immediate access to information (Agosto, 2002a; Weiler, 2005). Members of the i-Trust community consultation also commented on two time-related elements - the time they had available and the time they were willing to spend. Their decisions to use particular search engines were influenced by time-related factors, e.g. ease of use, speed, effective delivery of results, and immediacy of downloading. It was felt that possession of good information literacy/search skills could be time-saving and deliver better, more trustworthy results.

Propensity to trust and risk are individual characteristics that can impact on cognitive responses (McKnight and Kacmar, 2006; Kelton et. al., 2008). Studies of trust as a psychological attribute revealed that each person possesses a personality characteristic influencing their willingness to extend trust in specific situations (Rotter, 1980). The higher this propensity is in general, the more likely people are to trust in particular instances, including information seeking. Several authors on the concept of trust have highlighted the fact that the presence of risk creates a need for trust and that willingness - and freedom - to accept rather than 
reject that risk is a vital dimension of trust (Hardin, 2001). Risk features in many definitions of trust (Mayer et al., 1995) and, as Corritore et al., (2003) say, risk is particularly relevant in the online environment.

\section{How students use the web for research}

Several studies have asked students how they use the web in information seeking. The first port of call is generally commercial search engines such as Google or Yahoo (OCLC, 2002; Jones, 2002; Fallow, 2005; Head and Eisenberg, 2009) In some cases this is truer of undergraduates than postgraduates in some cases it is done in conjunction with course notes (Head and Eisenberg, 2009); and in others it is done even after students have received information skills training (Becker, 2003; Buschman and Warner, 2005, OCLC, 2005). Calicott and Vaughn (2006) and Wieklinski (2005) discuss the usefulness of this approach as a starting point. Wikipedia was mentioned by students, especially undergraduates, as being useful for background information at the start of a project (Jones et al., 2008; Wong et al., 2009)

In fact, members of the i-Trust community consultation indicated that they used Google first (in two cases to the exclusion of other search engines). Membership of the i-Trust community consultation comprised academics, researchers, managers, etc as well as students so it may be that, although the research reviewed herein covers students, members of these other groups exhibit similar characteristics. Few members said they would use library websites and this was a less likely starting point than use of a search engine (Johnson-Yale et al., 2008) especially for undergraduate as opposed to postgraduate students.

In terms of searching techniques, research indicates that there is reliance on past experience of successful searching in starting a new search and this may account for a tendency for students to follow the same pattern in the initial stages irrespective of the information goals (Head and Eisenberg, 2009). Members of the i-Trust community consultation also indicated that they tended to go to their favoured search engine first irrespective of the information sought, because they were familiar with it and had past positive experiences when using it to find information.

Research indicates that websites are chosen in an arbitrary/haphazard manner and free web resources are used almost to the exclusion of library resources (Buschman and Warner, 2005). The library websites are seldom or infrequently used since students believe that other websites have 'better' information (OCLC, 2002, 2005)

The tables below illustrate students' perceptions of the library portal in comparison with the Internet and research papers comparisons of the library portal and the Internet. 


\begin{tabular}{|c|c|c|}
\hline Library portal & Internet & Reference \\
\hline Based on card catalogue & Intuitive interfaces & Breeding, 2006 \\
\hline Poorly ordered search results & Relevancy ranking & Breeding, 2006 \\
\hline $\begin{array}{l}\text { Complexities of Boolean } \\
\text { search }\end{array}$ & Search engine models & Breeding, 2006 \\
\hline $\begin{array}{l}\text { Organization - not always } \\
\text { helpful/understandable }\end{array}$ & $\begin{array}{l}\text { Cluttered - but users found } \\
\text { what they wanted! }\end{array}$ & $\begin{array}{l}\text { Fast and Campbell } \\
\text {,2004 }\end{array}$ \\
\hline Trustworthy & $\begin{array}{l}\text { Less trustworthy - but } \\
\text { confidence in evaluation }\end{array}$ & $\begin{array}{l}\text { Fast and Campbell, } \\
2004\end{array}$ \\
\hline $\begin{array}{l}\text { Modest expectations of } \\
\text { finding what wanted, less } \\
\text { confident }\end{array}$ & $\begin{array}{l}\text { High expectations of finding } \\
\text { what wanted, more confident }\end{array}$ & $\begin{array}{l}\text { Fast and Campbell, } \\
2004\end{array}$ \\
\hline Less up to date content & More up to date content & $\begin{array}{l}\text { Fast and Campbell, } \\
2004\end{array}$ \\
\hline $\begin{array}{l}\text { Slower in terms of time and } \\
\text { effort }\end{array}$ & $\begin{array}{l}\text { Faster in terms of time and } \\
\text { effort }\end{array}$ & $\begin{array}{l}\text { Fast and Campbell, } \\
2004\end{array}$ \\
\hline Control & Freedom & $\begin{array}{l}\text { Fast and Campbell, } \\
2004\end{array}$ \\
\hline $\begin{array}{l}\text { 'Ineffectual' admiration - i.e. } \\
\text { admirable but doesn't inspire } \\
\text { use! }\end{array}$ & Enthusiasm & $\begin{array}{l}\text { Fast and Campbell, } \\
2004\end{array}$ \\
\hline Passivity & Proactivity & $\begin{array}{l}\text { Fast and Campbell, } \\
2004\end{array}$ \\
\hline Complex & Simple & \\
\hline Deferred gratification & Immediate gratification & \\
\hline $\begin{array}{l}\text { Demanding of greater } \\
\text { understanding }\end{array}$ & $\begin{array}{l}\text { Undemanding of } \\
\text { understanding }\end{array}$ & \\
\hline Demanding in terms of skills & $\begin{array}{l}\text { Undemanding in terms of } \\
\text { skills }\end{array}$ & \\
\hline Intimidating & Non-threatening & $\begin{array}{l}\text { Fast and Campbell, } \\
2004\end{array}$ \\
\hline Frustrating & Facilitating & $\begin{array}{l}\text { Fast and Campbell, } \\
2004\end{array}$ \\
\hline Multiple approaches & One-stop shopping & $\begin{array}{l}\text { Head and Eisenberg, } \\
2009\end{array}$ \\
\hline $\begin{array}{l}\text { Unreliable, hit and miss -e.g. } \\
\text { embargos on current journals }\end{array}$ & $\begin{array}{l}\text { Expectations more likely to be } \\
\text { met by Google/Wikipedia in } \\
\text { terms of finding relevant info }\end{array}$ & Wong et al., 2009 \\
\hline
\end{tabular}

Table 1: Student perceptions of the library portal vs. the Internet 


\begin{tabular}{|c|c|c|}
\hline Library portal & Internet & Reference \\
\hline Quality of results superior & $\begin{array}{l}\text { Quality of results inferior } \\
\text { (G) }\end{array}$ & $\begin{array}{l}\text { Brophy and } \\
\text { Bawden, } 2005\end{array}$ \\
\hline Coverage inferior & Coverage superior $(\mathrm{G})$ & $\begin{array}{l}\text { Brophy and } \\
\text { Bawden, } 2005\end{array}$ \\
\hline Accessibility inferior & Accessibility superior(G) & $\begin{array}{l}\text { Brophy and } \\
\text { Bawden, 2005 }\end{array}$ \\
\hline Full text access $21 \%$ & Full text access $73 \%$ & Haya et al., 2007 \\
\hline Half \# documents found & Full \# documents found & Haya et al., 2007 \\
\hline $\begin{array}{l}\text { User interface fails to } \\
\text { conform to expectations, } \\
\text { can appear complex }\end{array}$ & $\begin{array}{l}\text { User interface conforms to } \\
\text { expectations, familiar, } \\
\text { minimalist }\end{array}$ & $\begin{array}{l}\text { Adlington and } \\
\text { Benda, 2006; Haya } \\
\text { et al., } 2007\end{array}$ \\
\hline Front end searching & Back end searching & Miller, 2005 \\
\hline $\begin{array}{l}\text { Meta searching can be } \\
\text { slower than Google }\end{array}$ & $\begin{array}{l}\text { Google can be faster than } \\
\text { meta searching }\end{array}$ & $\begin{array}{l}\text { Cathcart and } \\
\text { Roberts, } 2006\end{array}$ \\
\hline $\begin{array}{l}\text { Trusted for access and } \\
\text { location of materials }\end{array}$ & $\begin{array}{l}\text { Preferred for discovery of } \\
\text { information }\end{array}$ & York, 2006 \\
\hline $\begin{array}{l}\text { Search rules not } \\
\text { understood }\end{array}$ & Search rules understood & Haya et al., 2007 \\
\hline $\begin{array}{l}\text { Searching needs training } \\
\text { (what difference does this } \\
\text { make?) }\end{array}$ & Intuitive searching & $\begin{array}{l}\text { Miller, 2005; } \\
\text { Anderson, } 2006\end{array}$ \\
\hline $\begin{array}{l}\text { May need intermediaries } \\
\text { (will they seek help?) }\end{array}$ & Don't need intermediaries & $\begin{array}{l}\text { Miller, 2005; } \\
\text { Anderson, } 2006\end{array}$ \\
\hline $\begin{array}{l}\text { Librarianese } \\
\text { (author/title/subj searches) }\end{array}$ & User-picked search terms & Anderson, 2006 \\
\hline $\begin{array}{l}\text { Misunderstanding around } \\
\text { multiple word searches }\end{array}$ & $\begin{array}{l}\text { Understanding of multiple } \\
\text { word searches (AND } \\
\text { default) }\end{array}$ & Haya et al., 2007 \\
\hline Version control & $\begin{array}{l}\text { Multiple versions, e.g. } \\
\text { preprints, revisions and } \\
\text { final versions }(G S)\end{array}$ & $\begin{array}{l}\text { Tenopir, 2005; } \\
\text { Adlington and } \\
\text { Benda, } 2006\end{array}$ \\
\hline $\begin{array}{l}\text { Unhelpful for } \\
\text { multidisciplinary or } \\
\text { transdisciplinary searches }\end{array}$ & $\begin{array}{l}\text { Particularly useful for } \\
\text { multidisciplinary and } \\
\text { transdisciplinary searches }\end{array}$ & $\begin{array}{l}\text { Adlington and } \\
\text { Benda, } 2006\end{array}$ \\
\hline
\end{tabular}

Table 2: Comparisons of the library portal and the Internet from the literature

Table continued over page... 


\begin{tabular}{|c|c|c|}
\hline Library portal & Internet & Reference \\
\hline $\begin{array}{l}\text { Results not ranked in a } \\
\text { meaningful way }\end{array}$ & $\begin{array}{l}\text { Popularity-based rankings } \\
\text { using non-specialised } \\
\text { language. Help at early } \\
\text { stages of learning subject }\end{array}$ & Thelwall, 2006 \\
\hline $\begin{array}{l}\text { Retrievals closely linked to } \\
\text { search terms so relevant } \\
\text { and manageable }\end{array}$ & $\begin{array}{l}\text { Numerous hits but too few } \\
\text { pertinent to the search - } \\
\text { managing these can be at } \\
\text { the expense of evaluating } \\
\text { their content, potential to } \\
\text { miss the 'best' }\end{array}$ & $\begin{array}{l}\text { Anderson, 2006; } \\
\text { Cathcart and } \\
\text { Roberts, 2006; } \\
\text { Donlan and Cooke, } \\
2006\end{array}$ \\
\hline $\begin{array}{l}\text { Using library portal might } \\
\text { alert to hard copy } \\
\text { material/books that might } \\
\text { contain better (i.e more } \\
\text { relevant/complete/accurate) } \\
\text { info }\end{array}$ & $\begin{array}{l}\text { Using GS is less likely to } \\
\text { alert user to existence of } \\
\text { better } \\
\text { (relevant/complete/accurate) } \\
\text { material in hard copy } \\
\text { format - i.e. on library } \\
\text { shelves! }\end{array}$ & Anderson, 2006 \\
\hline $\begin{array}{l}\text { Subject analysis via subject } \\
\text { thesauri in databases }\end{array}$ & $\begin{array}{l}\text { Federated search engine } \\
\text { dependent on KW searching } \\
\text { - only as good as subject } \\
\text { headings included (GS) }\end{array}$ & $\begin{array}{l}\text { Gross and Taylor, } \\
\text { 2005; Donlan and } \\
\text { Cooke, } 2006\end{array}$ \\
\hline $\begin{array}{l}\text { Invisible web content of } \\
\text { quality (e.g. high quality } \\
\text { medical resources) but } \\
\text { esoteric? Minority interest? }\end{array}$ & $\begin{array}{l}\text { Some 'invisible web' } \\
\text { content inaccessible for } \\
\text { technical/political/economic } \\
\text { reasons (but meets most } \\
\text { user needs, i.e. popular) } \\
\text { (GS) }\end{array}$ & $\begin{array}{l}\text { Anderson, 2006; } \\
\text { Egger-Sider and } \\
\text { Devine, 2006; } \\
\text { Herring, 2005 }\end{array}$ \\
\hline $\begin{array}{l}\text { Business model - provision } \\
\text { of list of material used to } \\
\text { 'compile' results. FX scope } \\
+ \text { authority. }\end{array}$ & $\begin{array}{l}\text { Business model - doesn't } \\
\text { provide list of material used } \\
\text { to compile sources. FX } \\
\text { scope + authority (GS) }\end{array}$ & $\begin{array}{l}\text { Adlington and } \\
\text { Benda, } 2006\end{array}$ \\
\hline $\begin{array}{l}\text { Do librarians understand } \\
\text { users' web-based } \\
\text { behaviour. Are they/should } \\
\text { they be responding to this? }\end{array}$ & $\begin{array}{l}\text { Google understanding } \\
\text { users' Web-based behaviour } \\
\text { and responding to this. }\end{array}$ & $\begin{array}{l}\text { Phipps and } \\
\text { Maloney, } 2006\end{array}$ \\
\hline \multicolumn{3}{|l|}{$\mathrm{G}=$ Google } \\
\hline
\end{tabular}

Table 2 (cont): Comparisons of the library portal and the Internet from the literature 
It would appear from tables 1 and 2 that there is a gulf between how information is organised in/retrieved from libraries and student understanding of that organisation/retrieval (Becker, 2003).

A concern is that students will rely exclusively on search engines such as Google Scholar for their research (York, 2006). Such an approach has the potential to compromise the quality of their search results and, concomitantly, the quality of the resultant assignments (Grimes and Boening, 2001) and inhibits the development of information literacy skills (Anderson, 2006).

If there is lack of differentiation between the free web and trusted resources chosen and paid for by the library (Buschman and Warner, 2005) then it is possible that there will be lack of recognition for the library and even that users may be duped into paying for content to which the library already subscribes (York, 2006). Library portals may be undermined by search engines such as Google Scholar, in using Google Scholar, the portal or gateway can be bypassed, as can the librarians as gatekeepers (Phipps and Maloney, 2006). This could mean that students could graduate from HE without using the academic library or scholarly information (Donlan and Cooke, 2006) and, worst possible scenarios, libraries and librarians could become irrelevant/redundant (York, 2006)

In fact, by the time an HE student arrives at university, searching habits and information seeking behaviours have already been adopted. It is vital that trust, as an element of information literacy, is seen as a continuum and education providers need to address this issue from primary education onwards. By working with teachers to identify where these skills lie in their existing curriculum, the librarian can support the teacher in developing pupils' abilities.

\section{Conclusion}

Questions that emerged from the i-Trust community consultation were; "Do librarians understand users' web-based behaviour. Are they/should they be responding to this?" If users continue to side-step expert library systems and rely on commercial search engines than the answer must be that no, information professionals would appear not to understand users' web-based behaviour and are unable to construct trusted portals that respond initiatively to that behaviour.

Fast and Campbell (2004) argue for redefining library portal/OPAC interface in line with Web-based standards of usability.

Web searching is shaping user expectations of what an information retrieval system looks like, how it behaves, and how to interact with it.

(Fast and Campbell, 2004, 138)

Much of the literature argues that libraries cannot compete with search engines such as Google Scholar so their best strategy is to take inspiration from and emulate them (Massey-Burzio, 2002; Lackie, 2006) and to collaborate with them and other stakeholders in the development of systems that deliver quality and convenience (Bell, 2004; Egger-Sider, 2006). Such collaborative endeavours could result in the development of a trusted portal that provides the ease of use associated with commercial search engines whilst still providing more advanced retrieval, storage and analysis options. Investment by libraries includes licences 
and software packages; time and effort in purchasing decisions; numerous technology-related investments; and ICT support and training including continuing professional development (CPD). In addition to the benefits for students, there are potential benefits for librarians such as improved interaction with users; improved understanding of user needs; improved understanding of their own CPD/experience/knowledge; recognition as an 'expert' or professional; and general job satisfaction.

\section{References}

Adlington, J. and Benda, C. (2006) Checking under the hood, Internet Reference Services Quarterly, 10(3), 135-148.

Agosto (2002a). Bounded rationality and satisficing in young people's web-based decision-making, Journal of the American Society for Information Science and Technology, 53(1), 16-27.

Agosto, D. E. (2002b). A model of young people's decision-making in using the Web, Library and Information Science Research, 24(4), 311-341.

Amichai-Hamburger, Y., Fine, A. and Goldstein, A. (2004) Impact of Internet activity and need for closure on consumer preference, Computers in Human Behavior, 20, 103-117.

Amichai-Hamburger, Y., Kaynar, O. and Fine, A. (2007) Effects of need for cognition on Internet use, Computers in Human Behavior, 23(1), 880-891.

Anderson, R. (2006) The (uncertain) future of libraries in a Google world, Internet Reference Services Quarterly, 10(3), 29-36.

Anderson, R. (2010) Scholarly communications: the view from the library. In: Woodward, H. L. E. (ed.) Digital information: order or anarchy. London, Facet.

Becker, N. J. (2003). Google in perspective: understanding and enhancing student search skills, New Review of Academic Librarianship, 9(1), 84-100.

Bell, S. (2004) The Infodiet: how libraries can offer an appetizing alternative, Chronicle of Higher Education, B15.

Bilal, D. (2000). Children's use of the Yahooligans! Web search engine: 1. Cognitive, physical, and affective behaviors on fact-based search tasks, Journal of the American Society for Information Science, 51, 646-665.

Bradley, R. (2005) Digital authenticity and integrity: Digital cultural heritage documents as research resources, PORTAL, 5(2), 165-176.

Braten, I., H. I. Stromso, et al. (2009). Trust matters: examining the role of source evaluation in students' construction of meaning within and across multiple texts, Reading Research Quarterly 44(1), 6-28.

Breeding, M. (2006). Technology for the next generation, Computers in Libraries 26(10), 28-30. 
Brophy, J. and D. Bawden (2005). Is Google enough? Comparison of an Internet search engine with academic library resources, Aslib Proceedings: New Information Perspectives 6.

Burbules, N. C. (2001) Paradoxes of the web: The ethical dimensions of credibility, Library Trends, 49(3), 441-453.

Burhanna, K. J. et al. (2009). No natives here: a focus group study of student perceptions of Web 2.0 and the academic library, The Journal of Academic Librarianship 35(6), 523-532.

Buschman, J. and Warner, D. A. (2005) Researching and shaping information literacy initiatives in relation to the Web: some framework problems and needs, The Journal of Academic Librarianship, 31(1), 12-18.

Callicott, b. and Vaughn, D. (2006) Google Scholar vs. Library Scholar, Internet Reference Services Quarterly, 10(3), 71-88.

Calvert, P. J. (2001). Scholarly misconduct and misinformation on the World Wide Web, Electronic Library, 19(4), np.

Cathcart, R. and Roberts, A. (2006) Evaluating Google Scholar as a tool for information literacy, Internet Reference Services Quarterly, 10(3), 167-176.

Colaric, S. (2003) Instruction for Web searching: an empirical study, College and Research Libraries, 64, 112.

Corritore, C. L., Kracher, B. and Wiedenbeck, S. (2003) On-line trust: concepts, evolving themes, a model, International Journal of Human-Computer Studies, 58(6), 737-758.

Corriveau, K. and Harris, P. L. (2009) Preschoolers continue to trust a more accurate informant 1 week after exposure to accuracy information.

Developmental Science, 12, 188-193.

Dong, X. (2003) Searching information and evaluation of Internet: a Chinese academic user survey, International Information and Library Review, 35(2/4), 163-187.

Donlan, R. and Cooke, R. (2006) Running with the devil, Internet Reference Services Quarterly, 10(3), 149-157.

Egger-Sider, F. and Devine, J. (2006) Google, the invisible Web, and librarians, Internet Reference Services Quarterly, 10(3), 89-101.

Fallow, D. (2005) Search engine users: internet searchers are confident, satisfied and trusting-but they are also unaware and naive. Washington, DC: Pew Internet Research Center.

Fast, K. V. and D. G. Campbell (2004) "I still like Google": University student perceptions of searching OPACs and the Web, Proceedings of the American Society for Information Science and Technology, 41(1), 138-146.

Grimes, D. J. and C. H. Boening (2001). Worries with the web: A look at student use of web resources, College and Research Libraries 62(1), 11-23. 
Gross, T. and Taylor, A. G. (2005) What have we got to lose? The effect of controlled vocabulary on keyword searching results, College and Research Libraries, 66(3), 212-230.

Haya, G., Nygren, E. and Widmark, W. (2007) Metalib and Google Scholar: a user study, Online Information Review, 31(1), 365-375

Head, A. J. and M. B. Eisenberg (2009). How college students seek information in the digital age. Project Information Literacy Progress Report. Washington DC, Information School, University of Washington.

Hembroff, L.A. (2006) MSU student health assessment: Spring 2006 [online]. URL: www.ippsr.msu.edu/Publications\%5Cacha_2006_RPT_LAH.pdf [accessed 04.01.12].

Herring, J.E. (2004) The Internet and information skills. London: Facet Publishing

Herring, M. Y. (2005) A gaggle of Googles: limitations and defects of electronic access as panacea, Internet Reference Services Quarterly, 10(3-4), 37-44.

Hertzum, M., Andersen, H.H.K., Andersen, V, and Hansen, C.B. (2002). Trust in information sources: Seeking information from people, documents, and virtual agents, Interacting with Computers, 14(5), 575-599.

Hung, T. Y. (2004). Undergraduate students' evaluation criteria when using web resources for class, Journal of Educational Media and Library Sciences. 42(1), $1-12$.

Jones, S. (2002) The Internet goes to college: how students are living in the future with today's technology. Washington DC: Pew Research Center.

Kaynar, O. and Amichai-Hamburger, Y. (2008) The effects of need for cognition on Internet use revisited, Computers in Human Behavior, 24(2), 361-371.

Kelton, K., Fleischmann, K. R. and Wallace, W. A. (2008) Trust in digital information, Journal of the American Society for Information Science and Technology, 59(3), 363-374.

Kolsto, S.D. (2001). To trust or not to trust,... "pupils' ways of judging information encountered in a socio-scientific issue, International Journal of Science Education, 23(9), 877-901

Kuhlthau, C.C. (1991). Inside the search process: Information seeking from the user's perspective, Journal of the American Society for Information Science, 42, 361-371.

Kuhlthau, C.C. (1993a). A principle of uncertainty for information seeking. Journal of Documentation, 49(4), 339-355.

Kuhlthau, C.C. (1993b). Seeking meaning: A process approach to library and information services. Norwood, NJ: Ablex.

Lappin, J. and McLeod, J. (2010) Investigation into the use of Microsoft SharePoint in Higher Education Institutions: Final Report. Eduserv funded 
project. [online]. URL: www.northumbria.ac.uk/static/5007/ceispdf/SPAp1.pdf [accessed 04.01.12].

Lim, S. (2009). How and why do college students use Wikipedia? Journal of the American Society for Information Science and Technology, 60(11), 2189 - 2202

Liu, Z. (2004). Perceptions of credibility of scholarly information on the web, Information Processing and Management, 40(6), 1027-1038.

Liu, Z. and X. Huang (2005). Evaluating the credibility of scholarly information on the web: A cross cultural study, The International Information and Library Review, 37(2), 99-106.

Lynch, C. A. (2001) When documents deceive: trust and provenance as new factors for information retrieval in a tangled web, Journal of the American Society for Information Science and Technology, 52(1), 12-17.

Manual, K. (2002) Teaching information literacy to Generation Y, Journal of Library Administration, 36(1-2), 195-217.

Mayer, M. A. et al. (2006) MedIEQ - Quality labelling of medical web content using multilingual information extraction, Studies in Health Technology Information, 121, 183-190.

McKnight, D. H. Choudhury, V. and Kacmar, C. (2002) The impact of initial customer trust on intentions to transact with a web site: a trust building model, Journal of Strategic Information Systems, 11(3/4), 297-323.

McKnight, D. H. and Kacmar, C. (2006) Factors of information credibility for an Internet advice site, HICSS '06 Proceedings of the 39th Annual Hawaii International Conference on System Sciences, 6, 113.2.

Metzger, M. J. (2007). Making sense of credibility on the Web: Models for evaluating online information and recommendations for future research, Journal of the American Society for Information Science And Technology, 58(13), 20782091.

Metzger, M. J., Flanagin, A.J. and Zwarun, L. (2003). College student Web use, perceptions of information credibility, and verification behavior, Computers and Education, 41(3), 271-290.

Miller, W. (2006) Introduction: Libraries and their interrelationships with Google, Internet Reference Services Quarterly, 10(3), 1-4.

OCLC: Online Computer Library Center (2002) OCLC white paper on the information habits of college students: How academic librarians can influence students' web-based information choices [online]. URL: http://web.mnstate.edu/schwartz/informationhabits.pdf [accessed 04.01.12].

OCLC: Online Computer Library Center (2005) Perceptions of libraries and information resources [online]. Dublin, OH: OCLC. URL:

http://www.oclc.org/reports/2005perceptions.htm [accessed 05.01.12].

Phipps, S. E. and Maloney, K. (2006) Choices in the Paradigm Shift, Internet Reference Services Quarterly, 10(3), 103-115. 
Pickard, A. J., Gannon-Leary, P. and Coventry, L. (2010) Users' trust in information resources in the Web environment: a status report [online]. London: JISC. URL: http://ierepository.jisc.ac.uk/470/2/JISC_User_Trust_final_report.pdf [accessed 05.01.12].

Pickard, A. J. (2008) Rich pictures: Researching the role of peer interaction for pupils using the internet, Popular Narrative Media, 1(2), 169-181.

Pickard, A. J. (2007) Research methods in information. London: Facet.

Pickard, A. J. (2005) The role of effective intervention in promoting the value of electronic information services in the learning process: Case studies in Higher Education, Performance Measurement and Metrics, 6(3), 172-182.

Princeton Survey Research Associates International. (2005) Leap of faith: Using the Internet despite the dangers: results of a national survey of Internet users for consumer reports. WebWatch, [online]. URL: http://www.consumerwebwatch.org/pdfs/princeton.pdf [accessed 05.01.12].

Rieh, S. Y. (2002). Judgment of information quality and cognitive authority in the Web, Journal of the American Society for Information Science and Technology, 53, 145-161.

Rotter, J. B. (1980) Interpersonal trust, trustworthiness and gullibility, American Psychologist, 35(1), 1-7.

Rouet, J.F. (2006). The skills of document use: From text comprehension to Webbased learning. Mahwah, NJ: Erlbaum.

Rowlands, I. (2008) The Google generation: the information behaviour of the researcher of the future, Aslib Proceedings: New Information Perspectives, 60(4), 290-310.

Swanson, T. (2007) Teaching students about information: information literacey and cognitive authority, Research Strategies, 20(4), 322-333.

Taraborelli (2008) How the web is changing the way we trust. In: Waelbers, K., Briggle, A. and Brey, P. (eds.) Current Issues in Computing and Philosophy. Amsterdam: IOS Press.

Tenopir, C. (2005) Google in the academic library, Library Journal, 130(2), 32.

Thelwall, M. (2006) Directing students to new information types, Internet Reference Services Quarterly, 10(3), 159-166.

Tsai, C.-C., Lin, S. S. J. and Tsai, M.-J. (2001) Developing an Internet Attitude Scale for high school students, Computers and Education, 37(1), 41-51.if

University College London (2008) Information behaviour of the researcher of the future. A CIBER briefing paper [online]. URL:

http://www.jisc.ac.uk/media/documents/programmes/reppres/gg final_keynote_1 1012008.pdf [accessed 05.01.12].

Usher, W. (2009) General practitioners' understanding pertaining to reliability, interactive and usability components associated with health websites, Behaviour and Information Technology, 28(1), 39-44. 
Wachbroit, R. (2000) Reliance and reliability: The problem of information on the internet. Report from the Institute for Philosophy and Public Policy, 20(4), 9-15.

Walsh, P. (2007) Content labels, explained in plain English [online]. URL: http://segala.com/blog/content-labels-explained-in-plain-english/ [accessed 05.01.12].

Wang, P., and Soergel, D. (1998). A cognitive model of document use during a research project. Study I. Document selection, Journal of the American Society for Information Science, 49, 115-133.

Weiler, A. (2005). Information seeking behaviour in Generation Y students: motivation, critical thinking and learning theory, Journal of Academic Librarianship 31(1), 46-53.

Wieklinski, J. M. (2005) Studying Google Scholar: wall to wall coverage? Online, 29(3), 22-26.

Wong, W., H. Stelmaszewska, et al. (2009). User behaviour in resource discovery: Final report. JISC User behaviour observational study, JISC.

York, M. C. (2006) Calling the scholars home, Internet Reference Services Quarterly, 10(3), 117-133.

\section{Acknowledgement}

This study was funded by the Joint Information Systems Committee (JISC) as part of the JISC Information Environment Programme. We would like to acknowledge Benn Wynne for his support in defining and scoping this project as well as all of those who contributed to the Community Consultation'.

\section{Open access and copyright}

Library and Information Research is an open access journal. A freely available copy of this paper may be downloaded from the journal's website: http://www.cilipjournals.org.uk/lir

Copyright and associated moral rights in works published in Library and Information Research are retained by the author(s) but this paper may be used freely, with proper attribution, in educational and other non-commercial settings. 